\title{
PENDAMPINGAN PENYUSUNAN DED BIO DIGESTER KEL. AGUNG LAWANGAN, KOTA PAGARALAM
}

\author{
Dian Pratnamas \\ Program Studi Teknik Sipil; Sekolah Tinggi Teknologi Pagaralam (STTP) \\ Jl. M. Siagim No. 75. Karang Dalo, Dempo Tengah, Kota Pagar Alam \\ Telp/Fax: (0730) 621916 \\ e-mail:dianspsttp@gmail.com
}

\begin{abstract}
Abstrak
Satu kebijakan Pemerintah Indonesia adalah pemanfaatan atau pengolahan limbah kotoran ternak sebagai energi alternatif (biogas) skala rumah tangga yang ramah lingkungan untuk memenuhi keperluan rumah tangga itu sendiri. Biogas biasanya dikenal sebagai gas rawa atau lumpur. Gas campuran ini didapat dari proses perombakan kotoran ternak menjadi bahan organik oleh mikroba dalam kondisi tanpa oksigen (anaerob). Selama proses fermentasi, biogas pun terbentuk. Sumber energi biogas dapat dimanfaatkan ditengah-tengah kelangkaan energi minyak bumi. Penggunaan dari energi biogas sebagai bahan bakar berdampak positif karena mengurangi pencemaran lingkungan. Sangat diharapkan penggunaan teknologi baru ini dapat dimanfaatkan oleh masyarakat ditengah kelangkaan energi minyak bumi dan harga minyak bumi yang cukup melambung pada masa kini.Biodigester adalah suatu sistem yang mempercepat pembusukan bahan organik. Darinya terbentuk biogas dan senyawa-senyawa lain yang dihasilkan melalui pembusukan anaerob. Biogas tersebut dapat digunakan untuk bahan bakar memasak, memanaskan, pembangkit listrik, juga menjalankan mesin.
\end{abstract}

Kata kunci- Pemerintah, Ternak, Biogas, Bumi, Organik, Memasak.

\section{PENDAHULUAN}

Tingkat pertumbuhan penduduk Indonesia yang tinggi mengakibatkan jumlah sampah yang dihasilkan juga bertambah. Setiap masyarakat selalu menghasilkan limbah berupa aktifitas masyarakat yang telah busuk. Sejauh ini, permasalahan pengolahan sampah tersebut dapat diminimalkan dengan menerapkan pengolahan sampah yang terpadu (Integrated Solid Waste Management/ISWM), diantaranya waste to energy atau pengolahan sampah menjadi energi Salah satu bentuk energi yang dihasilkan dari sampah adalah biogas, yaitu energi terbarukan yang dibuat dari bahan buangan organik berupa sampah, kotoran ternak, jerami, eceng gondok serta bahan lainnya melalui proses anaerob. Sampah buah mengandung bahan organik yang tinggi, sehingga potensial menjadi bahan baku produksi biogas.

Gas yang pertama kali dihasilkan merupakan campuran biogas dengan udara, sehingga dapat meledak jika kena api. Untuk itu jauhkan dan jangan dibakar atau dimanfaatkan untuk memasak. Buang gas bersama udara hingga habis, benamkan kembali drum kecil hingga dasar bak. Gas yang dihasilkan kemudian merupakan biogas yang diharapkan, dapat dimanfaatkan. Biogas dari unit tersebut dapat dimanfaakan untuk memasak makan malam; sambung ujung selang dengan kompor dengan mengatur campuran udara secara teliti; Jika udara kurang, maka akan menyala kuning; jika udara terlalu banyak, maka api akan mati; bila udara cukup, maka nyala berwarna biru, panas yang dihasilkan optimal; Aliran udara juga sering terganggu oleh jelaga sehingga nyalanya kuning; bersihkan; Adanya air dalam saluran gas juga dapat menghambat aliran gas, sehingga menyala tidak tetap atau lemah

\section{METODE}

Teknik yang digunakan dalam penyampaian materi pendampingan adalah workshop, dengan menggunakan alat bantu berupa laptop, LCD. 


\subsection{Materi}

Biogas adalah gas yang berasal dari makhluk hidup yaitu hewan dan tanaman. Biogas diproduksi oleh bakteri dari bahan organik di dalam kondisi hampa udara (anaerobik proses). Proses ini berlangsung selama pengolahan atau fermentasi, gas tersebut sebagian besar berupa metan dengan rumus molekul $\mathrm{CH}_{4}$ dan karbon dioksida dengan rumus molekul $\mathrm{CO}_{2}$. Campuran gas tersebut bersifat mudah terbakar jika kandungan metan mencapai lebih dari $50 \%$. Biogas yang berasal dari kotoran ternak berisi kira-kira $60 \%$ metan. Potensi produksi gas dari suatu jenis bahan sesungguhnya cukup tinggi jika kadar bahan organiknya juga tinggi dan tingkat rasio $\mathrm{C} / \mathrm{N}$ 20:1 sampai 40:1. Kecepatan produksi gas selanjutnya tergantung dari kondisi fisik bahan dan temperatur. Bahan kering dan berserabut lebih lama jika dibandingkan dengan bahan yang halus serta basah. Temperatur optimal padasuhu 35 C, berkisar antara $32-37$ C. Selain itu juga tergantung dari jenis bakterinya. Kelompok bakteri yang berbeda bertugas untuk kehidupan fermentasi dalam sebuah ekosistem. Setiap jenis bakteri tergantung dengan jenislainnya. Jangka fermentasi menjadi singkat jika populasi bakteri benar-benar seimbang. Kadar kering (total solid = TS) lapisan yang tidak terolah, berkisar antara $7-11 \%$. Hasil ini bisa dicapai jika kotoran padat dicampur air atau urine dengan volume yang seimbang. Proses digester yang sehat menunjukkan adanya $\mathrm{pH} 7.0$ (taraf netral dari bahan). Bila bakteri yang menghasilkan metan telah tersedia dalam bahan misalnya dari kotoran ruminansia, produksi biogas dimulai dalam waktu 3 - 5 hari. Pada lahan pertanian digester di isi perlahan-lahan, sementara itu penggunaannya setelah bangunan penuh terisi. Bila ada masalah untuk mengawali produksi gas (missal udara terlalu dingin), maka perlu ditambah $20 \%$ kotoran pemacu yang berasal dari digester yang telah berfungsi, kemudian diaduk pada saat pengisian pertama.

\subsection{Pembuatan Biodigester;}

Biodigester sering disebut bangunan biogas yaitu sebuah tabung tertutup tempat limbah organic difermentasi, sehingga menghasilkan gas bio sebagai energy disertai dengan bahan penyubur dari limbah organik. Ada 3 jenis:

1. Digester permanen (Fixed Dome Digester);

2. Digester Terapung (Floating Dome Digester);

3. Digester ditutup plastik (Plastic Covered Ditch);

\subsection{Penempatan Biodigester;}

Biodigester ditempatkan denganjarak 10 meter dari bangunan rumah dan 15 meter dari sumber air. Hal ini dilakukan berdasarkan pertimbangan keamanan. Jangan terlalu jauh karena akan memerlukan selang yang panjang. Selang yang melintasi jalan sebaiknya ditanam agar tidak mudah bocor. Letak biogas juga mempertimbangkan suhu optimal antara $32-37$ C. Untuk daerah panas, digester sebaiknya ditempatkan di tempat teduh, naungan pohon atau bangunan sederhana sebagai pelindung. Sedangkan untuk daerah dingin tempatkan langsung di bawah sinar matahari sehingga terjamin suhunya. Selain itu juga sebaiknya digester ditanam dalam tanah ditutup tanah dan lapisan jerami untuk memelihara suhu.

\subsection{Pembuatan Campuran Pembangkit (starter);}

Untuk mengolah bahan yang tidak mengandung bakteri fermentasi semisal dari kotoran ayam, perlu dibuatkan campuran pembangkit fermentasi dengan cara:

- Campurkan 2 liter kotoran ternak sapi dengan 2 liter air;

- Aduk secara merata; tuang campuran tersebut pada jerigen yang memuat 4 liter atau lebih, atau pakai stoples atau botol besar asal tidak ditutup;

- Atur suhu pembangkit, guncang-guncangkan guci 3 - 4 kali dalam seminggu untuk mengaduk isinya;

- Simpan selama 2 bulan, sehingga siap pakai;

\subsection{Pengoperasian Digester;}


Siapkan 3 ember limbahdan 3 ember air diaduk secara sempurna dalam drum besar; Masukkan lagi masing-masing 3 ember air dan limbah sesuai kapasitas drum besar, aduk lagi; Tambahkan dan aduk campuran pembangk ia dengan bahan yang ada pada drum besar; Tempatkan drum kecil pada drum besar dengan posisi lubang selang ada di atas, tekan hingga menyentuh dasar drum besar; Tutup keran dalam keadaan ruang drum kecil penuh terisi oleh campuran bahan biogas, yang penting tidak ada udaranya lagi; Tunggu hingga gas terbentuk dalam drum kecil. Produksi gas terbentuk dalam waktu 3 minggu, bahkan dapat satu bulan. Setelah itu sekitar 8 minggu; Selama 8 mingggu separoh dari gas diproduksi dalam $2-3$ minggu pertama dan sisanya dalam 5-6 minggu terakhir; Jika pada akhir minggu dari waktu di atas tidak banyak gas yang diproduksi, maka unit itu harus dikosongkan dan mulailah dari awal;

\subsection{Perawatan Biodigester}

Jika suhu lingkungan $<15 \mathrm{C}$, maka suhu campuran limbah dalam unit biogas harus tetap dipelihara dengan cara menanam unit biogas dalam tanah; Cara lain dengan menimbuni drum unit dengan jerami atau tongkol jagung; Untuk memelihara panas juga dapat menambahkan satu bagian kotoran unggas dengan 3 bagian kotoran ruminan; Kemungkinan drum mengalami kebocoran, hal ini dapat dideteksi dengan menggunakan air sabun; oleskan pada tempat yang dicurigai, jika terbentuk gelembung, maka bocornya di situ; Jika ada bocoran, maka perlu ditambal dengan menggunakan bahan tambal yang sesuai apakah logam atau plastik;

\section{HASIL DAN PEMBAHASAN}

Berikut merupakan pembahasan hasil yang didapat pada saat pelaksanaan pengabdian, yaitu sebagai berikut:

\subsection{Hasil}

Pelaksanaan pendampingan penyusunan DED biodigester memberikan pengetahuan tentang metode yang tepat untuk digunakan dalam aplikasi proses pembuatan biogas.

\subsection{Pembahasan}

Biogas adalah gas yang dihasilkan dari proses penguraian bahan-bahan organic oleh mikroorganisme pada kondisi langka oksigen (anaerob). Komponen biogas antara lain sebagai berikut: $\pm 60 \% \mathrm{CH}_{4}$ (metana), $\pm 38 \% \mathrm{CO}_{2}$ (karbondioksida) dan $\pm 2 \% \mathrm{~N}_{2}, \mathrm{O}_{2}, \mathrm{H}_{2}, \& \mathrm{H} 2 \mathrm{~S}$. Biogas dapat dibakar seperti elpiji, dalam skala besar biogas dapat digunakan sebagai pembangkit energy listrik, sehingga dapat dijadikan sumber energy alternatif yang ramah lingkungan dan terbarukan.

Biogas yang dihasilkan oleh aktivitas anaerobic sangat popular digunakan untuk mengolah limbah biodegradable karena bahan bakar dapat dihasilkan sambil menghancurkan bakteri pathogen dan sekaligus mengurangi volume limbah buangan. Metana dalam biogas, bila terbakar akan relative lebih bersih daripada batubara, dan menghasilkan energi yang lebih besar dengan emisi karbondioksida yang lebih sedikit.

Pemanfaatan biogas memegang peranan penting dalam manajemen limbah karena metana merupakan gas rumah kaca yang lebih berbahaya dalam pemanasan global bila dibandingkan dengan karbondioksida. Karbon dalam biogas merupakan karbon yang diambil dari atmosfer oleh fotosintesis tanaman, sehingga bila dilepaskan lagi ke atmosfer tidak akan menambah jumlah karbon di atmosfer bila dibandingkan dengan pembakaran bahan bakar fosil. Saat ini, banyak Negara maju meningkatkan penggunaan biogas yang dihasilkan baik dari limbah cair maupun limbah padat atau yang dihasilkan dari sistem pengolahan biologi mekanis pada tempat pengolahan limbah.

Prinsip pembuatan biogas adalah adanya dekomposisi bahan organic secara anaerobik (tertutup dari udara bebas) untuk menghasilkan gas yang sebagian besar adalah berupa gas metan (yang memiliki sifat mudah terbakar) dan karbondioksida, gas inilah yang disebut biogas. Proses dekomposisi anaerobic dibantu oleh sejumlah mikroorganisme, terutama bakteri metan. Suhu yang baik untuk proses fermentasi adalah $30-55^{\circ} \mathrm{C}$, dimana pada suhu tersebut mikroorganisme mampu 
merombak bahan-bahan organic secara optimal. Berikut adalah Tata Letak Instalasi Digester Biogas Sampah Skala Kawasan

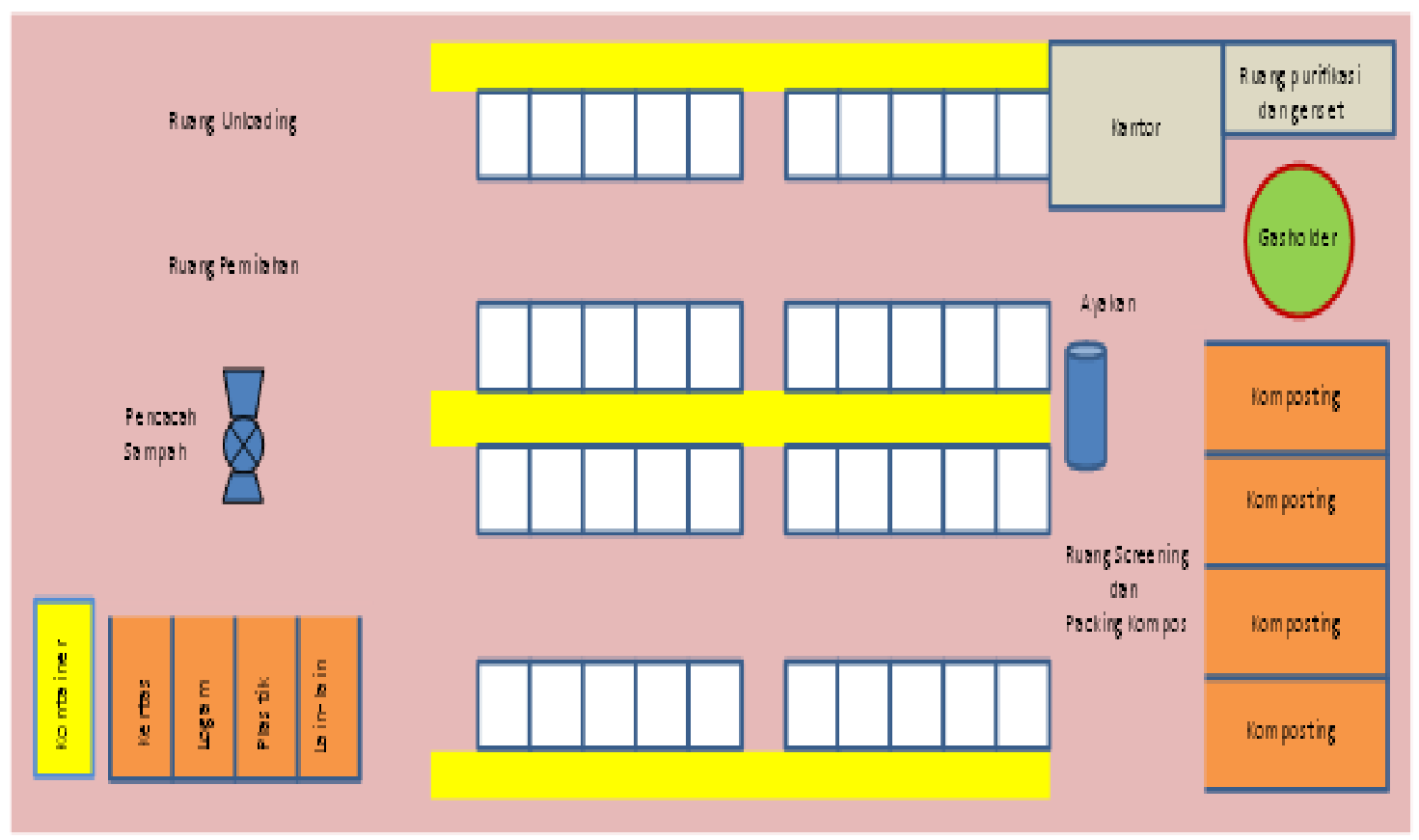

Pembuatan biogas dari sampah organik baik skala rumah tangga maupun skala kawasan memiliki prospek yang sangat baik.

\section{KESIMPULAN}

Biogas merupakan salah satu alternatif bahan bakar ramah lingkungan. Energi biogas dapat mengurangi pencemaran/ polusi pada lingkungan dan pengembangan alternatif biogas ini dapat meningkatkan pendapatan masyarakat.Manfaat energi biogas adalah sebagai pengganti bahan bakar khususnya minyak tanah dan dipergunakan untuk memasak kemudian sebagai bahan pengganti bahan bakar minyak (bensin, solar). Dalam skala besar, biogas dapat digunakan sebagai pembangkit energi listrik. Saat ini berbagai bahan dan jenis peralatan biogas telah banyak dikembangkan sehingga dapat disesuaikan dengan karakteristik wilayah, jenis, jumlah dan pengelolaan kotoran ternak. Secara umum terdapat dua teknologi yang digunakan untuk memperoleh biogas. Pertama, proses yang sangat umum yaitu fermentasi kotoran ternak menggunakan digester yang didesain khusus dalam kondisi anaerob. Kedua, teknologi yang baru dikembangkan yaitu dengan menangkap langsung gas metan dari lokasi tumpukan sampah tanpa harus membuat digester khusus.

\section{SARAN}

SaranTersedianya sampah organik ini tentu tidak hanya dapat dimanfaatkan biogasnya saja, tetapi juga dimanfaatkan untuk pembuatan kompos serta pupuk cair. Melalui pemanfaatan ini, lingkungan akan menjadi self-sustainable, yang artinya apa yang dihasilkan dari sampah organik vegetasi dapat digunakan juga sebagai pupuk untuk penanaman kembali atau memberi nutrisi pada vegetasi yang sudah ada. Dengan demikian penggunaan alat tersebut diharapkan dapat menjadi salah satu solusi mengatasi kerusakan lingkungan dari penumpukan sampah serta berkontribusi dalam penghijauan dan penghematan energi.Pembangunan biodigester untuk pengolahan limbah agroindustri cukup menarik minat masyarakat, karena pengolahan limbah industri ini mampu mengurangi beban masyarakat terhadap kebutuhan energi bahan bakar dan listrik, sehingga perlu dikembangkan di berbagai lokasi, terutama lokasi pedesaan dan sentra-sentra agroindustry. 


\section{UCAPAN TERIMA KASIH}

Penulis mengucapkan terima kasih kepada Panitia dan LPPM.

\section{DAFTAR PUSTAKA}

[1] Muslim, B. 2018. Pelatihan aplikasi editing video dengan filmora., Laporan Pengabdian Kepada Masyarakat, LPPM STT Pagaralam.

[2] Paimin, Farry, B. 1995. AlatPembuatan biogas Dari Drum. Jakarta: PenebarSwadaya.

[3] Setiawan, A.I. 2008. MemanfatkanKotoranTernak. Cet 14. Jakarta: PenebarSwadaya.

[4] Simamora, S. et al. 2006. Membuat Biogas PenggantiBahanBakarMinyak Dan Gas Dari KotoranTernak. Jakarta: AgroMedia Pustaka.

[5] Soewarno, N., A. Sato, Muchayat. Pengolahan Sampah Organik untuk Memproduksi Biogassebagai Energi Terbarukan: Seminar Nasional Teknik Kimia Indonesia - SNTKI, 2009.

[6] Isro'Mukti, Y. (2017). Sistem Informasi Madrasah Aliyah Negeri Pagar Alam Berbasis Web. Indonesian Journal of Computer Science, 6(2), 192-205.

[7] Mukti, Y. (2017). Perencanaan Strategis Sistem Informasi Dan Teknologi Informasi Pada Sekolah Menengah Kejuruan Negeri 2 Pagar Alam. JURNAL ILMIAH BETRIK: Besemah Teknologi Informasi dan Komputer, 8(02), 83-92.

[8] Arif, A., \& Mukti, Y. (2017). Rancang Bangun Website Sekolah Menengah Pertama (SMP) Negeri 8 Kota Pagar Alam. JURNAL ILMIAH BETRIK: Besemah Teknologi Informasi dan Komputer, 8(03), 156-165.

[9] Isro'Mukti, Y. (2018, October). Sistem Informasi Manajemen Aset Sekolah Tinggi Teknologi Pagaralam Berbasis Web. In Seminar Nasional Teknologi Informasi dan Komunikasi (SEMNASTIK) (Vol. 1, No. 1, pp. 632-638).

[10] Mukti, Y. (2018). Rancang Bangun Website Sekolah Dengan Metode User Centered Design (UCD). JURNAL ILMIAH BETRIK: Besemah Teknologi Informasi dan Komputer, 9(02), 84-95. 